\author{
Anna Gierusz \\ University of Gdańsk \\ e-mail: anna.gierusz@ug.edu.pl
}

\title{
COLLECTIVE AND INDIVIDUAL DC PENSION SCHEMES: COMPARING BENEFIT AMOUNTS RECEIVED BY MEMBERS
}

\section{ZBIOROWY A INDYWIDUALNY PROGRAM EMERYTALNY O ZDEFINIOWANEJ SKLADCE: PORÓWNANIE ŚWIADCZEŃ UZYSKANYCH PRZEZ UCZESTNIKÓW}

DOI: $10.15611 /$ nof.2017.4.05

JEL Classification: G22, J32

Summary: Occupational pension schemes in Poland are all defined contribution (DC) in nature. The contribution amount is fixed, whereas the benefit amount is unknown and depends on many factors such as contributions paid and investment returns received. The risk in a DC scheme is borne by the member, who may not be equipped with the financial knowledge needed to manage such a risk. A solution applied by some countries takes the form of collective DC schemes, where the risk is borne collectively by all members of such a scheme. The aim of this paper is to describe collective DC schemes functioning in selected countries and to compare the benefit amounts which the members can receive from collective and from individual DC schemes. The results show that the variability of benefit amounts in a collective DC scheme is lower than in a traditional DC scheme. An additional safeguard, which allows to improve the financial condition of a collective DC scheme in cases of low investment returns has been proposed.

Keywords: occupational pension schemes, defined contribution pension schemes, collective DC schemes.

Streszczenie: Pracownicze programy emerytalne (PPE) funkcjonujące w Polsce to programy o zdefiniowanej składce (defined contribution, DC). Wysokość składki jest z góry określona, nieznana jest natomiast wysokość świadczenia, która zależy od wielu czynników, m.in. takich jak suma wpłaconych składek i stopa zwrotu z inwestycji. Ryzyko związane z nieznaną wysokością świadczenia w tym typie programu ponosi uczestnik, który może nie mieć odpowiedniej wiedzy do podejmowania decyzji finansowych lub inwestycyjnych w celu zmniejszenia ryzyka. Rozwiązaniem stosowanym w niektórych krajach są programy zbiorowe DC (collective DC schemes), w których ryzyko ponoszą wspólnie wszyscy ich uczestnicy. Celem artykułu jest charakterystyka programów zbiorowych oraz porównanie wysokości świadczenia, jakie mogą uzyskać uczestnicy programu zbiorowego i tradycyjnego, indywidualnego programu o zdefiniowanej składce. Wykazano, iż wysokość świadczenia 
uzyskiwanego z programu zbiorowego charakteryzuje się mniejszą zmiennością niż wysokość świadczenia z programu tradycyjnego. Rozważone zostało też dodatkowe zabezpieczenie, które umożliwia poprawę kondycji finansowej programu zbiorowego w razie niekorzystnych warunków finansowych.

Slowa kluczowe: pracownicze programy emerytalne, programy emerytalne o zdefiniowanej składce, programy zbiorowe DC.

\section{Introduction}

Occupational pension schemes in Poland are defined contribution (DC) in nature. The contributions (set as either level amount or a percentage of member's salary) are fixed, whereas the benefit amount, which the member will receive on retirement, is unknown. It depends on many factors, such as contributions paid, rate of return received on the scheme's investments and administration and management fees. The risk of the unknown benefit amount in such a scheme is borne by the member. For example, if the rate of investment return is lower than expected, the benefit amount received will decrease. Members of DC schemes are not necessarily equipped with the financial or investment knowledge sufficient to ensure that the required benefit is received [Davis 2013, p. 685]. A solution can take the form of a collective DC scheme, in which the risk is borne collectively by all members. The aim of this paper is to characterise collective DC schemes and compare the benefit amounts which can be received by members of a selected collective scheme and an individual scheme. For this purpose, models of such schemes which allow to calculate the benefit amount of each member have been constructed.

\section{Collective DC schemes}

Contributions in a collective DC scheme, just as in a traditional, individual DC scheme, are fixed in advance. In contrast to the traditional scheme, in which each member has an individual account to accumulate contributions and investment returns, contributions in a collective scheme are paid into one fund. A target benefit amount, which the scheme aims to provide each member with, is set. Every year or every couple of years a valuation of the scheme's liabilities is performed. The present value of the targeted benefits is calculated and compared with the value of scheme's assets. In cases of a deficit the contributions may be increased, or the benefit amount may be decreased. As a result, the risk is borne by all members. Apart from risk sharing, collective DC schemes also benefit from economies of scale, resulting in lower administration costs [Bikker, de Dreu 2007].

For this reason collective DC schemes, in particular those functioning in the Netherlands, are often described in the literature and proposed as a good solution for occupational pensions [van der Wurff et al. 2009; Schouten, Robinson 2012; 
Bonenkamp, van de Ven, Westerhout 2007]. The contributions in the Netherlands are fixed for a minimum period of five years, subsequently they can be changed but only as a result of negotiations between the employer sponsoring the scheme and the employees [Schouten, Robinson 2012, p. 336]. Depending on the financial condition of the scheme, the benefit amount (based on member's average salary) can be increased or decreased [Dutch Association of Industry-wide Pension Funds, Dutch Association of Company Pensions Funds 2013, p. 19]. However, the lack of possibility for individual investment and risk management decisions, as well as the lack of transparency regarding ownership rights have been mentioned as a disadvantage of this system [Bovenberg, Gradus 2015; Boender et al. 2007]. In Denmark, contributions paid into collective schemes can only be varied as a result of renegotiations between the employer and the employees. To calculate the benefit amount a minimum guaranteed rate of return and guaranteed annuity rates are used [Pugh, Yermo 2008, p. 34]. In Iceland, part of contributions is paid into a collective DC scheme and part into a traditional DC scheme. The collective scheme is required to provide the member with a minimum benefit amount, equal to $1.4 \%$ of salary for each year of scheme service. Funds collected in the traditional DC scheme are used to provide an additional benefit [Guðmundsson et al. 2014, pp. 8-10; OECD 2015, p. 211]. Other countries where collective schemes are introduced or considered include the US and Canada. In a research report [Turner 2014, pp. 9-12] compares collective schemes in the US and the Netherlands, whereas [Munnell, Sass 2013] describe a new collective scheme introduced in Canada. Several research projects into the benefits of hybrid pension schemes focus on or include collective DC schemes [Blommestein et al. 2009; Verheijden 2010; Khorasanee 2012].

In the US, a new collective pension scheme called SAFE has been proposed [Davis, Madland 2013]. Contributions are paid into a common fund. Each member has a notional account, which serves as a vehicle to track contributions and investment returns credited to the member. The manner in which investment returns are credited to members is as follows: an upper and lower limit for the rate of return is set, for example $0 \%$ and $8 \%$. If the actual rate of return on the scheme's investments is between those limits, the notional account of the member is credited with this actual rate. If the actual rate is higher than $8 \%$, the notional account value is increased by $8 \%$ and the rest of the returns is accumulated in a "reserve fund". If the actual rate of return is below $0 \%$, the notional account's value does not change (it is increased by $0 \%$ ) and the deficit is covered with the reserve funds. The financial condition of the scheme is assessed using a ratio of the scheme's asset value and the value of all notional accounts. The benefit takes the form of a lifetime annuity [Davis, Madland 2013, pp. 15-16].

In the next sections of the paper a model of a pension scheme based on the SAFE scheme will be presented. The SAFE scheme was chosen as a basis for a collective scheme for two reasons. Firstly, the way the benefit is calculated resembles that of an individual scheme (the value of member's account at retirement is used to calculate 
the level of the future pension), making the results for SAFE and the individual scheme comparable. Secondly, it is possible to adjust the SAFE model into one where the benefit does not take the form of a lifetime annuity but a one-off lump sum, which is the only option of benefit available in Polish occupational schemes. The benefit amounts received by members of such a scheme will be calculated. An analogous model of an individual DC scheme will be created. The only difference between the two models will be the way investment returns are credited to members, allowing to investigate the effect of risk sharing in a collective scheme.

\section{Assumptions for the collective scheme model}

In practice, each pension scheme would choose different assumptions based on its rules (such as contribution rate and retirement age), membership profile (number of members at each age) and investment strategy. The assumptions set out in this paper represent only one possibility. All the assumptions and calculations are based on real values. The notional account of each member is credited with an annual contribution equal to $4 \%^{1}$ of member's salary (the whole contribution can be financed by the member, or by the employer, or it can be divided between these two parties). The contributions are paid annually in arrears. The initial annual salary of each member is equal to 36,000 PLN (twelve times the median value, which in Poland was equal to around 3,000 PLN per month [GUS 2015, p. 1]), and the annual rate of salary growth is $1 \%$. A management fee equal to $0.5 \%^{2}$ of the value of the notional account is paid every year. Each member joins the scheme aged 25, pays contributions for forty years and retires aged 65 . For the first forty years of the scheme's functioning the number of members grows from one to forty, and remains forty thereafter (each member retiring at the age of 65 is immediately replaced with a new member aged $25)$. The benefit takes the form of a lump sum equal to the value of member's notional account at their retirement (this is the only benefit form available in Polish occupational schemes). The lower and upper limit for the rate of return credited to members is $0 \%$ and $4 \%$. In this way the real value of member's account will not decrease.

The same assumptions are used to model the traditional, individual DC scheme with one exception - the lower and upper limits for rate of return do not apply (the account of each member is credited with the actual rate of investment return).

Next, three scenarios concerning the values of rate of investment return will be considered: a moderate, pessimistic and optimistic one.

${ }^{1}$ In a document describing changes planned to occupational pension schemes, the Polish government proposed a contribution rate of $4 \%$ as a minimum rate payable into such schemes [Ministerstwo Rozwoju, 2016].

2 The proposed changes to Polish occupational pension schemes also include a cap on fees equal to $0.6 \%$ of funds [Ministerstwo Rozwoju 2016]. 


\section{Moderate scenario}

Moderate scenario assumes that the annual rates of investment return are independent and identically distributed random variables, following a normal distribution with mean $2 \%$ and standard deviation $4 \%$. A set of 100 rates of return (one for each scheme year under consideration) was drawn from this distribution. The benefit amounts (taking the form of a lump sum equal to the value of member's notional account) for the first sixty members retiring from the scheme have been calculated. The mean benefit amount equals 89,089 PLN, with a standard deviation of 5,654 PLN. The lowest amount received is 81,617 PLN, and the highest 101,451 PLN.

For the same assumptions, the benefit amounts for sixty members of the traditional DC scheme have been calculated. The mean benefit amount equals 81,188 PLN with a standard deviation of 13,272 PLN. The lowest benefit amount received is 63,462 PLN and the highest 109,159 PLN. The benefit amount for each member is shown in Figure 1.

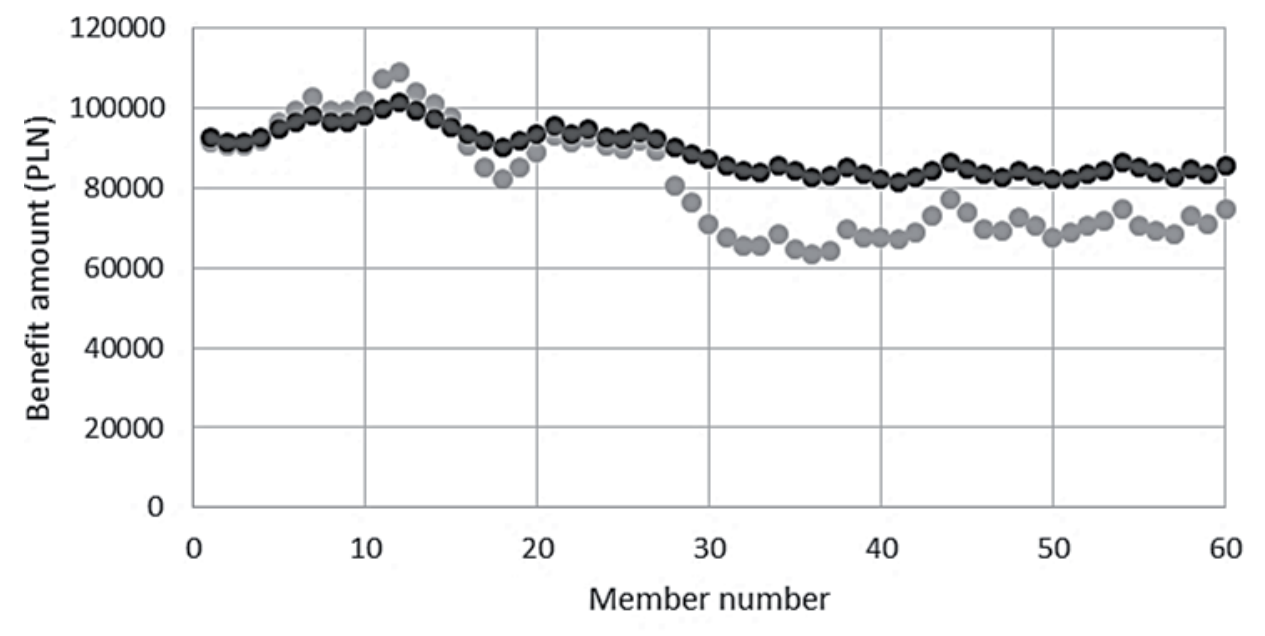

Individual scheme

- Collective scheme

Fig. 1. Benefit amount received by the first sixty members retiring from the collective scheme and analogous amount from the individual scheme - moderate scenario

Source: own work.

As shown in Figure 1, the benefit amount received by members of the collective scheme is less variable than the amount from the individual scheme. Depending on the financial conditions, members of the individual scheme can receive benefits that are much higher or lower, indicating greater risk compared with members of the collective scheme. 


\section{Pessimistic scenario}

In this scenario the expected value of rate of investment return is lower - annual rates of return are independent and identically distributed random variables, following a normal distribution with mean $0 \%$ and standard deviation $4 \%$. A set of 100 rates of return (one for each scheme year under consideration) was drawn from this distribution. The mean benefit amount equals 83,381 PLN, with a standard deviation of 3,840 PLN. The lowest amount received is 76,063 PLN, and the highest 90,458 PLN.

For the same assumptions the benefit amounts for sixty members of the traditional DC scheme have been calculated. The mean benefit amount equals 66,646 PLN with a standard deviation of 6,511 PLN. The lowest benefit amount received is 54,160 PLN and the highest 80,441 PLN.

The mean benefit amount from the collective scheme decreased slightly by $6 \%$ in comparison with the moderate scenario. Both the lowest and highest benefit amounts received also decreased. The benefit amount from the individual scheme is more sensitive to a change in financial conditions. The mean benefit amount decreased by $18 \%$. The benefit amount for each member is shown in Figure 2.

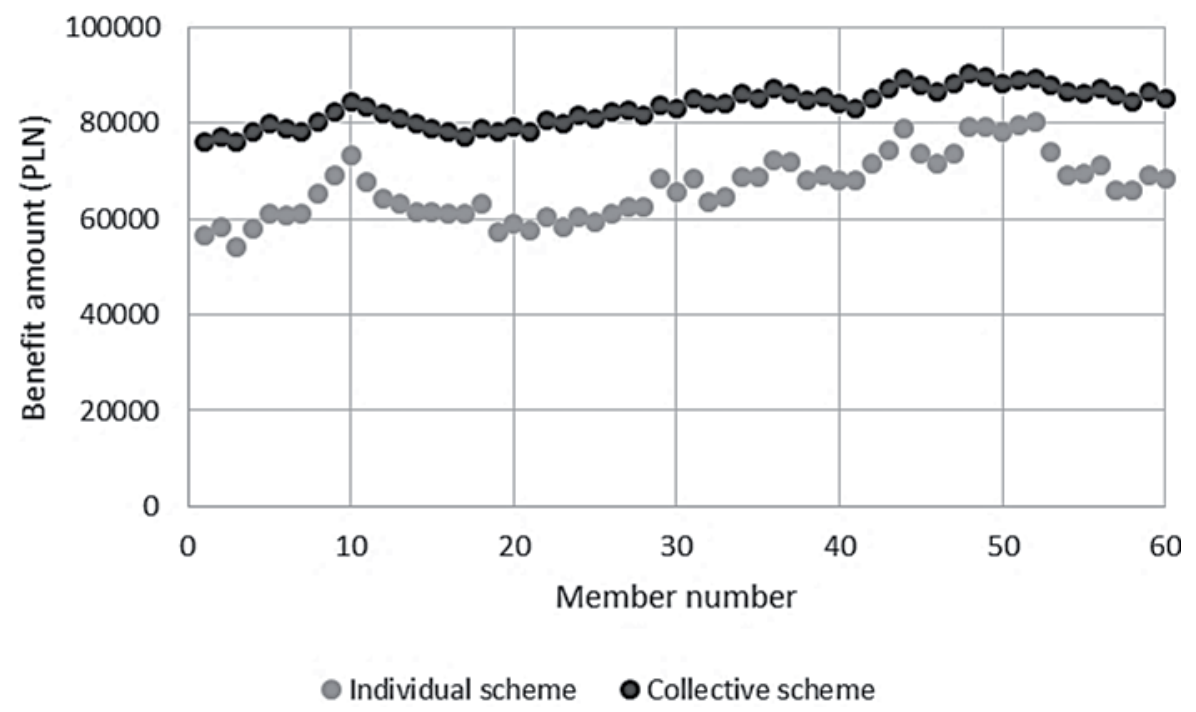

Fig. 2. Benefit amount received by the first sixty members retiring from the collective scheme and analogous amount from the individual scheme - pessimistic scenario

Source: own work.

As shown in Figure 2, the benefit amounts received from the individual scheme are lower than those from the collective scheme. A guarantee of a minimum rate of return of $0 \%$ protects the members of the collective scheme from a huge loss in years with low investment returns. In the individual scheme there is no such protection. 


\section{Optimistic scenario}

Optimistic scenario assumes that the expected value of the rate of return is higher annual rates of return are independent and identically distributed random variables, following a normal distribution with mean $4 \%$ and standard deviation $4 \%$. A set of 100 rates of return (one for each scheme year under consideration) was drawn from this distribution. In this case the mean benefit amount received in the collective scheme equals 106,014 PLN, with a standard deviation of 5,360 PLN. The lowest amount received is 94,876 PLN, and the highest 116,549 PLN.

For the same assumptions the benefit amounts for sixty members of the traditional DC scheme have been calculated. The mean benefit amount equals 123,555 PLN with a standard deviation of 22,490 PLN. The lowest benefit amount received is 88,937 PLN and the highest 165,158 PLN.

The mean benefit amount from the collective scheme increased in comparison with the moderate scenario by $19 \%$. The benefit amount from the individual scheme is more sensitive to changes in financial conditions - the mean benefit amount increased by $52 \%$. The benefit amount for each member is shown in Figure 3.

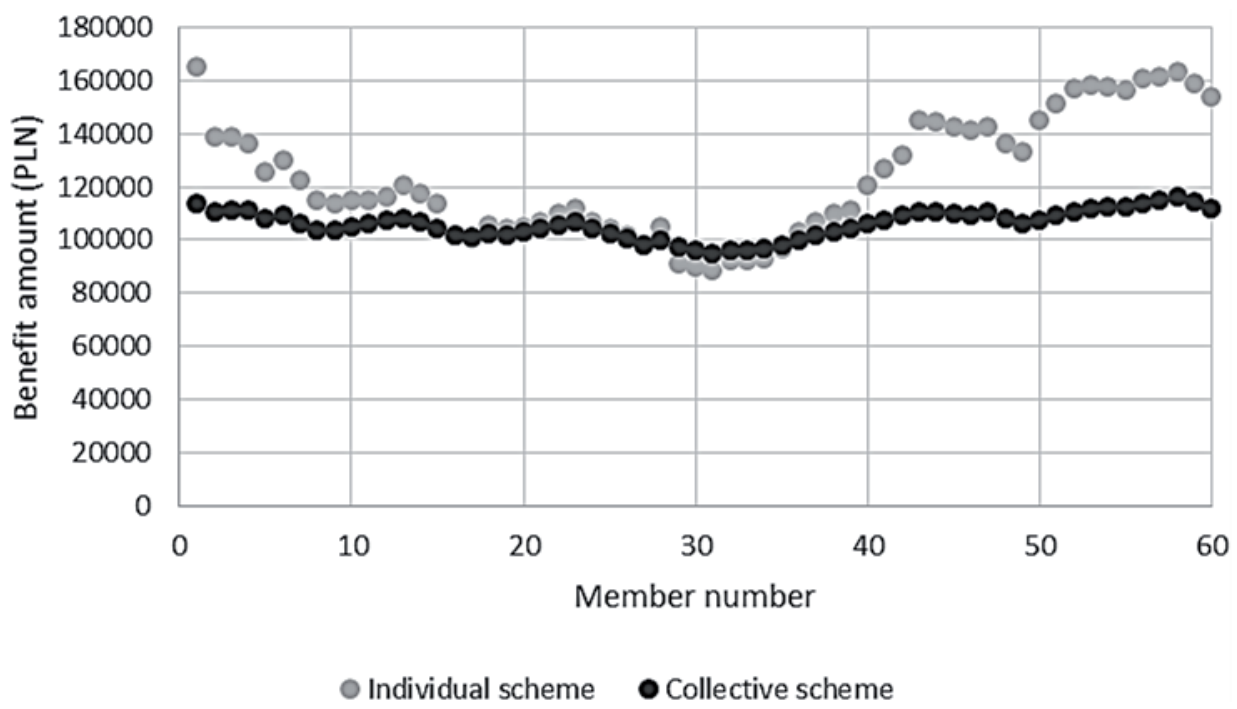

Fig. 3. Benefit amount received by the first sixty members retiring from the collective scheme and analogous amount from the individual scheme - optimistic scenario

Source: own work.

As shown in Figure 3, the benefit amounts received by members of the collective scheme are mostly lower than those from the individual scheme. This is caused by the upper limit for the rate of return credited to the members of the collective scheme, meaning that lower funds are accumulated in the notional accounts compared with accounts in the individual scheme. 


\section{Modification of the collective scheme by introduction of additional safeguard}

Setting lower and upper limits for the rate of return credited to members of the collective scheme can result in a deficit or surplus of funds. If the actual rate of return is higher than the upper limit, extra funds will be accumulated in the reserve fund. If the actual rate is lower than the lower limit, reserve funds will be used to increase value of members' notional accounts [Davis, Madland 2013, p. 24].

In order to monitor the financial condition of the scheme a current-value ratio proposed by [Davis, Madland 2013] can be used. This is a ratio of the value of the scheme's assets and the value of the notional accounts of all members. Its value at the end of each year was calculated. A value greater than $100 \%$ means surplus of funds, lower than $100 \%$ indicates a deficit of funds. Figure 4 presents the currentvalue ratio for the three scenarios under consideration in the first 100 years of the scheme functioning.

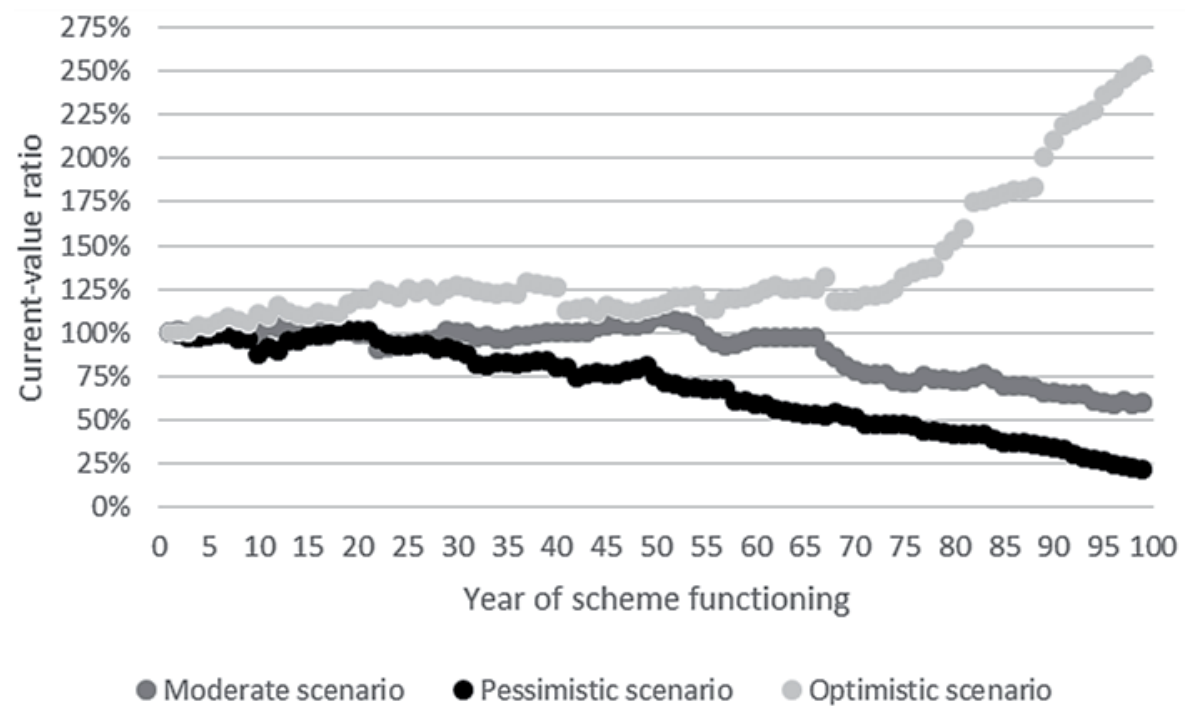

Fig. 4. Current-value ratio for the collective scheme for the three scenarios under consideration Source: own work.

In the case of the moderate scenario the current-value ratio remains at around $100 \%$, although after year 60 it starts to decrease. This is caused by low investment returns. The optimistic scenario assumes high investment returns, causing currentvalue ratio to increase up to $253 \%$ in year 99 . On the other hand, under the pessimistic scenario the ratio falls to $22 \%$ in year 99 .

The problem of deficit of funds is crucial for a collective scheme. There are many possible solutions, for example additional contributions may be paid or benefit 
$120 \%$

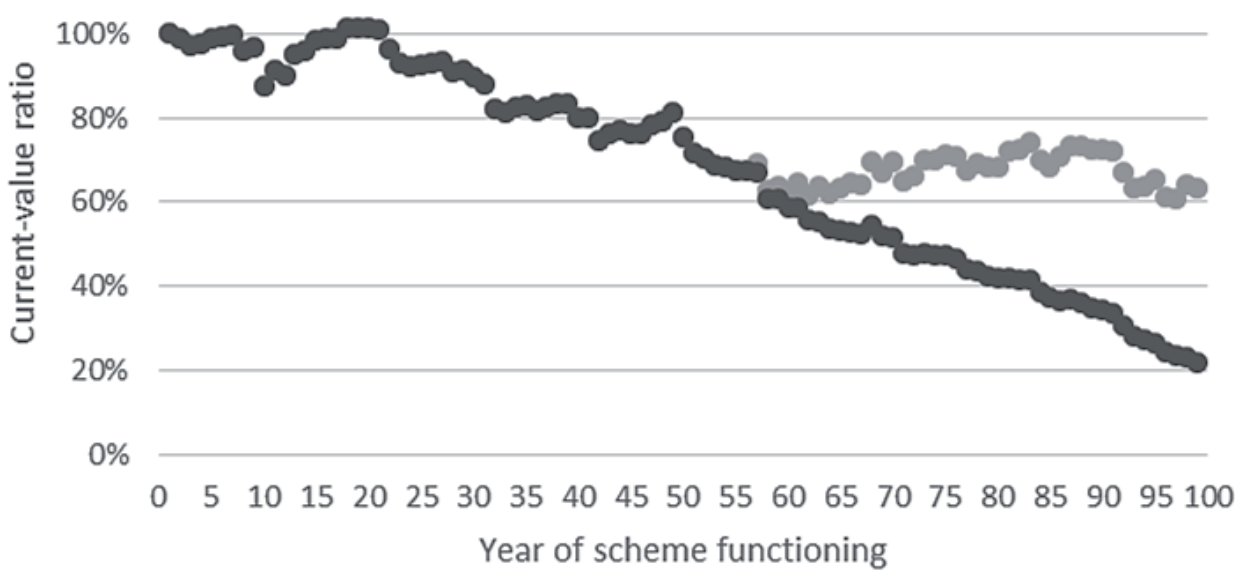

With additional safeguard $\quad$ Without additional safeguard

Fig. 5. Current-value ratio of a collective scheme with and without additional safeguard under the pessimistic scenario

Source: own work.

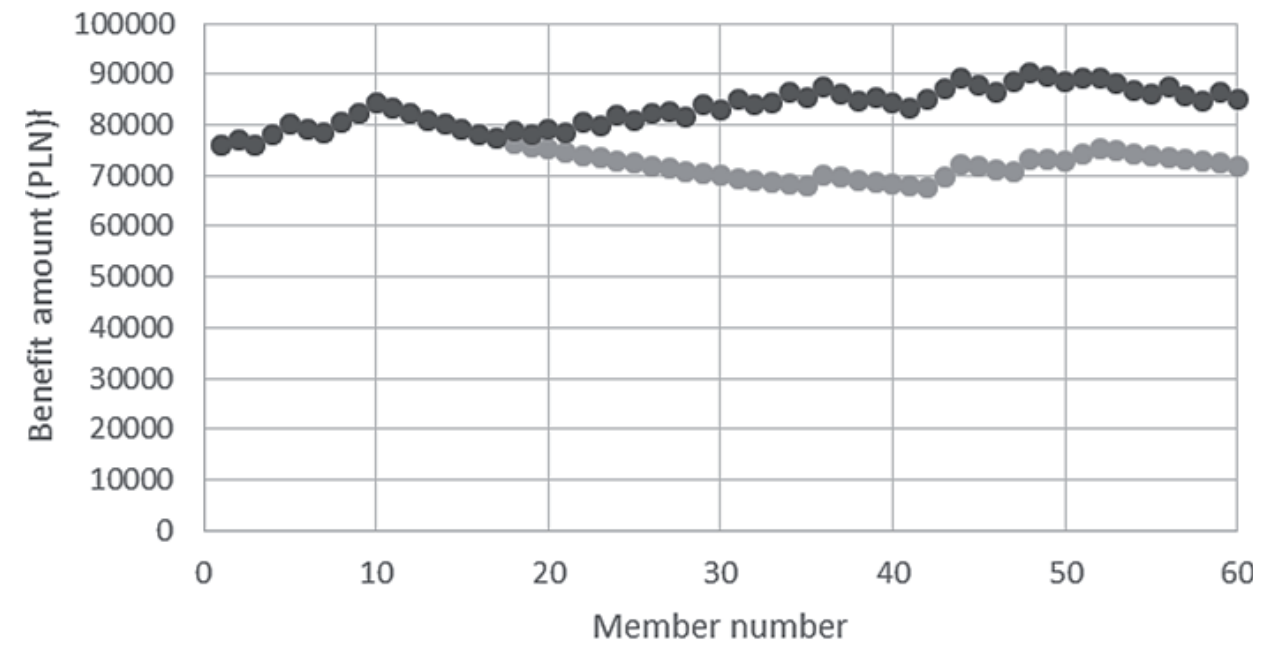

- With additional safeguard $\quad$ Without additional safeguard

Fig. 6. Benefit amount received from the collective scheme with and without the additional safeguard under the pessimistic scenario

Source: own work. 
amounts may be decreased [Davis, Madland 2013, p. 35]. In this paper a new solution, in the form of additional safeguard, has been proposed. Every year, before the notional accounts of members are credited with the rate of return, the currentvalue ratio is considered. If it is greater than $70 \%$, the rate of return is credited according to the rules described before. However, if the ratio falls below $70 \%$, a rate of return of $0 \%$ is credited (i.e. the notional account value does not change), independently of the actual rate of investment return. Consequently, in years when the financial condition of the scheme is weak, high returns are not credited to members but used to improve the fund. Figure 5 presents the current-value ratio of the collective scheme with and without the additional safeguard under the pessimistic scenario.

Figure 5 indicates that the introduction of the additional safeguard allows for the current-value ratio to be kept at a level of around $70 \%$ in years with low investment returns. Without such a safeguard the ratio decreases to around $20 \%$. However, such a modification of the scheme affects the benefit amounts received by members, as shown in Figure 6.

The additional safeguard allows for the current-value ratio to stay at a higher level. However, it simultaneously decreases the benefit amount received by members as it withholds some of the investment returns in order to improve the financial condition of the scheme. The mean benefit amount has decreased from 83,381 PLN to 73,989 PLN.

\section{Conclusion}

In a traditional individual DC scheme, risk is borne by the member who may not be well prepared for making financial or investment decisions in order to minimise risk. A solution can take the form of a collective DC scheme functioning in some countries. The paper presented a collective scheme, based on the SAFE scheme proposed in the US. A model used to calculate the benefit amounts received by members of such a scheme was constructed. These benefit amounts were compared with the benefits which the members could have received in an individual DC scheme. This has shown that the benefit amount received from the collective scheme is less variable than that from the individual scheme, hence in the collective scheme the member bears less risk. A similar conclusion was reached for a Dutch collective DC scheme by [Blommestein et al. 2009]. However, this was not the case for simulations performed by [Davis, Madland 2013]. Different investment strategies assumed for the SAFE and traditional DC plan in their work can be a reason for this result. Finally, an additional safeguard which allows for the financial condition of the scheme to be maintained at a desired level, was presented. 


\section{Bibliography}

Bikker J.A., de Dreu J., 2007, Operating costs of pension schemes, [in:] Steenbeek O.W., van der Lecq S.G. (eds.), Costs and Benefits of Collective Pension Systems, Springer.

Blommestein H., Janssen P., Kortleve N., Yermo J., 2009, Moving beyond the "DB vs DC" debate: The appeal of hybrid pension plans, Rotman International Journal of Pension Management, vol. 2, issue 2.

Boender C.G.E., Bovenberg A.L., van Hoogdalem S., Nijman T.E., 2007, Optimal risk sharing in private and collective pension contracts, [in:] Steenbeek O.W., van der Lecq S.G. (eds.), Costs and Benefits of Collective Pension Systems, Springer.

Bonenkamp J.P.M., van de Ven M.E.A.J., Westerhout E.W.M.T., 2007, Macroeconomic aspects of intergenerational solidarity, [in:] Steenbeek O.W., van der Lecq S.G. (eds.), Costs and Benefits of Collective Pension Systems, Springer.

Bovenberg L., Gradus R., 2015, Reforming occupational pension schemes: The case of the Netherlands, Journal of Economic Policy Reform, vol. 18, no. 3.

Davis R., 2013, The Tracker Plan: A controlled risk defined contribution retirement program, J. Marshall Law Review, vol. 46, issue 3.

Davis R., Madland D., 2013, American Retirement Savings Could be Much Better, Center for American Progress.

Dutch Association of Industry-wide Pension Funds, Dutch Association of Company Pensions Funds, 2013, The Dutch pension system. An overview of the key aspects.

Guðmundsson B., Bennewitz B., Asgrímsson B.Z., Bragadóttir K.I., Haldórsson S., 2014, Retirement savings adequacy. Measurement in Iceland, The Financial Supervisory Authority in Iceland Research Project.

GUS, 2015, Struktura wynagrodzeń wedtug zawodów w październiku 2014 r., Notatka informacyjna, https://stat.gov.pl/obszary-tematyczne/rynek-pracy/pracujacy-zatrudnieni-wynagrodzenia-koszty-pracy/struktura-wynagrodzen-wedlug-zawodow-w-pazdzierniku-2014-r-,5,4.html.

Khorasanee M., 2012, Risk sharing and benefit smoothing in a hybrid pension plan, North American Actuarial Journal, 16(4).

Ministerstwo Rozwoju, 2016, Strategia odpowiedzialnego rozwoju-program budowy kapitalu, https:// www.mr.gov.pl/media/22008/ProgramBudowyKapitalu prezentacja.pdf.

Munnell A.H., Sass S.A., 2013, New Brunswick's new shared risk pension plan, Center for Retirement Research, Boston College.

OECD, 2015, Pensions at a Glance 2015: OECD and G20 indicators, OECD Publishing.

Pugh C., Yermo J., 2008, Funding regulations and risk sharing, OECD Working Papers on Insurance and Private Pensions, no. 17, OECD Publishing.

Schouten E., Robinson T., 2012, Defined ambition pensions - have the Dutch found the golden mean for retirement savings?, Pensions, vol. 17, issue 4.

Van der Wurff A., Lundbergh S., Laros R., 2009, Risk sharing in Dutch pension schemes, [in:] Defining ambition: Views from the industry on achieving risk sharing, NAPF.

Verheijden J., 2012, From average pay DB to collective DC. Defining the risk transfer, Netspar theses, Netspar. 